IOS Press

\title{
Supplemental LED growth light in remontant strawberry at high latitudes ${ }^{1}$
}

\author{
Rolf Nestby* and Nina Trandem \\ Bioforsk - Norwegian Institute for Agricultural and Environmental Research, Stjørdal, Ås, Norway
}

Received 22 October 2013; accepted 21 November 2013

\begin{abstract}
.
BACKGROUND: To grow remontant strawberries at high latitudes in autumn is challenging because of short days and low light levels. Nevertheless, current day and night temperatures in Norwegian coastal areas up to 63 degrees $\mathrm{N}$ are normally sufficient for growth and fruit development till early October, and even higher temperatures can be expected in the future according to climatic scenarios, with potential to prolong the growing season. However, light would be a minimum factor. It is therefore of interest to examine the effects of providing supplemental light when photosynthetic active radiation (PAR) falls below critical level for development of high fruit quality.

OBJECTIVE: To examine effects on fruit yield parameters, fruit tension, Brix ${ }^{\circ}$ and arthropod numbers, in order to investigate the potential of LED lighting using diodes giving red and blue light, as a means to prolong the growing season at northern latitudes. METHOD: In this two-year study remontant strawberry cvs 'Everest' and 'Rondo' were grown in high polytunnels. Two LED lighting levels (LED100 and LED300) were applied from $7 \mathrm{Pm}$ to $7 \mathrm{AM}$, whenever light intensity fell below $400 \mu \mathrm{mol} \mathrm{m}^{-2} \mathrm{~s}^{-1}$ from first week of September, and compared to ambient light (control). The LED300 was peaking at wavelengths of $460 \mathrm{~nm}$ and $660 \mathrm{~nm}$, respectively blue and red, and the relation between blue and red light was 1:8; LED100 delivered similar wavelengths but the blue to red relation was $2: 8$. Fruit yield, soluble solids $\left(\mathrm{Brix}^{\circ}\right)$, fruit firmness, temperature $\left({ }^{\circ} \mathrm{C}\right)$, dew point $\left({ }^{\circ} \mathrm{C}\right)$, and $\mathrm{PAR}$ light $\left(\mu \mathrm{mol} \mathrm{m}{ }^{-2} \mathrm{~s}^{-1}\right)$ were recorded. The experimental design was block with four replications. The lamps were hung with the light source $40 \mathrm{~cm}$ above top of canopy, giving a PAR radiation at top of canopy of LED100 and LED300 of respectively 900 and $258 \mu \mathrm{mol} \mathrm{m}^{-2} \mathrm{~s}^{-1}$.

RESULTS: LED improved fruit yield and quality, but more at 900 than at $258 \mu \mathrm{mol} \mathrm{m}^{-2} \mathrm{~s}^{-1}$. However, highest light level was probably beyond the saturation point for photosynthesis, at least in early morning and late evening and the last three weeks of the harvesting season, because of low temperatures. Some fruit yield was not harvested because of too low temperatures to achieve ripen fruits after mid-October. Arthropods were sampled from 'Rondo' leaves 2-3 times per season, and aphids, spider mites and predatory mites (introduced) were the most numerous groups. LED significantly decreased the number of spider mites in the autumn. CONCLUSIONS: LED lighting has potential as light source growing remontant strawberries in high polytunnels, when PAR radiation is below $400 \mu \mathrm{mol} \mathrm{m} \mathrm{m}^{-2} \mathrm{~s}^{-1}$. However, to benefit fully of the light it would be necessary to grow the plants in winter tunnels and add heating. That would increase the yields significantly compared with our results.
\end{abstract}

Keywords: Extended season, cultivars, fruit yield, fruit tension, Brix ${ }^{\circ}$, Tetranychus urticae, Neoseiulus cucumeris, aphids

\section{Introduction}

In mid-Norway strawberry is mainly grown in open fields with fruit harvest in July and August, giving a single crop that usually yields between one and two $\mathrm{kg} \mathrm{m}^{-2}$. To improve the Norwegian strawberry industry, more of the cropping area should be protected, e.g. by using polytunnels. Apart from obvious benefits like weather protection, earlier ripening and improved harvesting conditions, polytunnels may give an opportunity to harvest strawberries later in the season by growing remontant (day-neutral) cultivars instead of June-bearers (short-day dependent).

\footnotetext{
${ }^{1}$ Paper presented at 2nd International Strawberry Congress, Hoogstraten, Belgium, Sept. 4-6, 2013.

*Corresponding author: Rolf Nestby, Dr., Bioforsk, Grassland and Landscape Division, 7512 Stjørdal, Norway. Tel.: +47 95988530; Fax: +47 7482 2008; E-mail: rolf.nestby@bioforsk.no.
} 
The potential of remontant cultivars at high latitudes will increase in the future because of higher temperatures according to scenarios of climate change [9]. However, beyond 21 September northern latitudes $\left(63^{\circ} \mathrm{N}\right)$ have reduced day length and light level compared with central and southern Europe, and in spite of daytime growing temperatures near $20^{\circ} \mathrm{C}$ in polytunnels till early October, the net photosynthesis will gradually decrease [7, 15]. As a result fruit size and sugar level are negatively affected [11] and number and weight of unmarketable fruit increase [4]. Greenhouse experiments in southern Norway showed that additional light of 9000 Lux (aprox. $110 \mu \mathrm{mol} \mathrm{m}^{-2} \mathrm{~s}^{-1}$ ) appeared satisfactory for fruit quality in 'Korona' and 'Elsanta', but higher light intensities gave better yield [5]. Studies in South Korea indicated that there was no difference in photosynthetic rates between three cultivars at $15-25^{\circ} \mathrm{C}$, and light saturation point was observed at $400-600 \mu \mathrm{mol} \mathrm{m}^{-2} \mathrm{~s}^{-1}$ at $15-18^{\circ} \mathrm{C}$. In The Netherlands light saturation point of 'Primella' was observed at $800 \mu \mathrm{mol} \mathrm{m}{ }^{-2} \mathrm{~s}^{-1}$ at $20^{\circ} \mathrm{C}$ [2, 3]. In remontant strawberry $337.5 \mu \mathrm{mol} \mathrm{m}^{-2} \mathrm{~s}^{-1}$ initiated better growth than $225 \mu \mathrm{mol} \mathrm{m}^{-2} \mathrm{~s}^{-1}$, and more so at $25^{\circ} \mathrm{C}$ than $20^{\circ} \mathrm{C}$, with no difference between continuous and $16 \mathrm{hrs}$ light period [12]. In June-bearing 'Tochiotome' the photosynthetic rate was saturated at $1000 \mu \mathrm{mol} \mathrm{m}{ }^{-2} \mathrm{~s}^{-1}$, and it was not increased by temperatures above $20^{\circ} \mathrm{C}$ when the $\mathrm{CO}_{2}$ level was below $400 \mathrm{ppm}$ [22]. Later research shows that decrease of leaf photosynthetic rate in shade (70\% and 50\% sunlight tested), mainly is due to non- stomatal limitation closely related to decrease of Rubisco and FDPase [25].

Options to improve light conditions in late autumn are use of artificial light, reflective foils and breeding for more low-light effective cultivars. Artificial light is since long introduced in greenhouse growing and is effective. However, it is costly and a high proportion of the input energy in conventional lamps is transformed to heat, which in a standard polytunnel will be lost through structure openings. LED (light emitting diodes) could be the key to solve these problems because most of the energy is used to produce light of specific wavelengths. The cost of LED is still a problem, but they have longer life span than conventional lamps and the efficiency of the diodes, which still is too low, is gradually improved [13]. It should be noted that light colour are decisive for the photosynthetic effect, and that LED lamps can be tailored to fit the photosyntethic apparatus. When constant red light $\left(160 \mu \mathrm{mol} \mathrm{m}^{-2} \mathrm{~s}^{-1}\right) \mathrm{was}$ supplied with 0 to $60 \mu \mathrm{mol} \mathrm{m}^{-2} \mathrm{~s}^{-1}$ blue light, photosynthetic rate in strawberry leaves was highest at the highest amount of blue light; however, average photosynthetic efficiency of red light was 2.5 times higher than the one of blue light [24].

Strawberry plants can be host to many insects and mites. Arthropods are affected by light in a number of ways, both directly and through the host plants $[6,21]$. At high latitudes, the approach of winter is indicated by decreasing day length and light intensity as well as by changes in host plant quality. Supplemental light late in the season may mask these natural cues and thus potentially inhibit physiological (e.g. diapause induction) and behavioural (e.g. finding a suitable overwintering site) preparations for winter, resulting in poorer winter survival. Supplemental light may also change seasonal patterns of plant susceptibility to herbivores. For example, strawberry foliage has been found to be more resistant to two-spotted spider mite (Tetranychus urticae) in summer than in spring, probably due to day-length governing the production of compounds involved in plant defence $[8,16]$. Supplemental light in the autumn could then extend the period of resistance. In addition, supplemental light could influence T. urticae through its natural enemies. The phytoseiid mite Neoseiulus cucumeris, which preys on T. urticae and other small arthropods lays fewer eggs when light intensity is low [26], and may thus profit from additional light.

Arthropods are also sensitive to specific wavelengths, and the red and blue light in LED growth light can have a significant impact on physiology and behaviour of insects and mites [21]. For example, both red and blue light have been shown to interfere with the landing response of whiteflies [21], and blue light to promote diapause induction in T. urticae ([20].

In the present two-year study, two cultivars of remontant strawberry were grown in polytunnels with two levels of supplemental light given in autumn by using LED with blue and red lighting. The objective was to examine the effects on fruit yield parameters, fruit tension, Brix ${ }^{\circ}$ and arthropod numbers, in order to investigate the potential of LEDs to prolong the growing season at northern latitudes.

\section{Material and methods}

Small plug plants of 'Everest, and 'Rondo', of equal size and developmental stage, and delivered from the same propagator (Sagaplant AS, Norway), were planted in $12 \mathrm{~cm}$ pots using peat as growth medium. The pots were placed 
in greenhouse with day/night temperature of $20 / 12^{\circ} \mathrm{C}$ on 20 April 2011 . The plants were fertigated using standard solution for growth, and flower stalks were removed. The plants were planted in soil (silt loam with high level of humus in the top layer) 1 June 2011 for flowering and fruiting in closed polytunnel skinned with polyethylene foil "Luminance THB High UV $150 \mathrm{mu} 3$ season" (Visqueen, Haygrove England). The plants were planted in two rows $20 \mathrm{~cm}$ apart on beds with $25 \mathrm{~cm}$ plant space within row. The distance between beds was $145 \mathrm{~cm}$ from top to top and they were mulched with woven black polyethylene foil (L.O.G. Poly-fiberduk, Norway). Water and fertigation was provided by one drip line per bed and $50 \mathrm{~cm}$ drip distance; fertilizing once a week and else watered based on tensiometer readings.

The predatory mite Neoseiulus cucumeris was released 25 July in 2011 (in breeder sachets from Biobest) and 7 June in 2012 (sachets from Syngenta). Both years one sachet containing about 1000 mites, was placed per $1.5 \mathrm{~m}$ of row to prevent plant-feeding mites and thrips to reach damaging levels without exterminating them. No other plant protection measures were employed, except hand and chemical weeding on the foot-land.

Experimental design was block $(N=4)$ with two research factors: a) cultivar ('Rondo' and 'Everest') randomized within block and b) supplemental light for $12 \mathrm{hrs}$ per day (LED 100W, LED 300W and control) randomized within cultivar and block. Plot size was 20 plants. Two LED lamps were hung $40 \mathrm{~cm}$ above the top of the canopy with a distance of $15 \mathrm{~cm}$ between lamps. The experimental plot was 10 plants situated under the lamps. The LED 100W (Quasar light co., LTD, China) and LED 300W (Yong CL Optoelectronic Co. LTD, China) had blue to red ratio of $1: 4$ and $1: 8$, respectively. For both light intensities, wavelength peak of blue was $460 \mathrm{~nm}$ and red $630 \mathrm{~nm}$. LED lighting was started when ambient light level dropped below $400 \mu \mathrm{mol} \mathrm{m}^{-2} \mathrm{~s}^{-1}$ (12 and 8 September, respectively in 2011 and 2012). Light levels were measured at the top of the leaf canopy in $\mu \mathrm{mol} \mathrm{m} \mathrm{m}^{-2}$.

Yield parameters recorded were total yield, fresh yield (berries $\geq 25 \mathrm{~mm}$ diameter vertical on the stalk/tip-line), rot, mildew, crumblyness, and other ( $<25 \mathrm{~mm}$ diameter, injured by snails, birds etc.) and fruit size (g/fruit) weighted according to yield. Fruit tension (grams) was measured on 10 fruits using L100 Hunter (USA) spring gauge with a conical end pressed into the fruit flesh on the sun-exposed side halfway between sepal and tip, thereafter fruits were frozen in closed plastic boxes; brix value was registered in run-off juice after thawing the frozen berries within the boxes for one night at room temperature.

PAR radiation, temperature and dew-point were registered using $\mathrm{HOBO}^{\circledR}$ data logger (Onset Computer Corporation, Bourne, Ma, USA).

Arthropods were collected by sampling 10 trifoliate fully grown leaves (not from runners) randomly from each plot of 'Rondo' in early June (2012 only), mid-August and mid-October. Leaves were put in paper bags, one bag per plot, placed in polyethylene bags inside a cartoon box, and transported over night to Bioforsk Plant Health at Ås, Norway. Arthropods were removed from the leaves by a wash and sieve method [14], and kept in $70 \%$ alcohol until counting under a stereo microscope.

Statistics on fruit -yield and -quality parameters were undertaken using Proc glm, tabulate, graph and greplay [17]. The effect of light treatment on arthropod numbers were analysed by one-way ANOVA [10]. To normalize residuals, the counts per leaf sample were log-transformed.

\section{Results and discussion}

\subsection{Effect of LEDs on fruit yield parameters}

First experimental year (2011) 'Rondo' had higher fruit yield than 'Everest' the first three weeks of harvest. Thereafter 'Everest' yielded higher or equal to 'Rondo' (Fig. 1). Normally the plants would develop two crop cycles per year. However, because of late planting and establishment the spring cycle was strongly reduced yielding a low crop and are in later discussion included into cycle 1. The autumn cycle developed normally and the yields were highest in September and dropped gradually in October. Harvest was stopped 18 October because low temperatures at the dew point or lower for long periods each day caused delayed fruit ripening and high percentage rotted fruits (Fig. 2). Thus, a large part of the crop was not harvested. There was no interaction between cultivar and LED for yield, $\%$ salable fruit, $\%$ fruit infected by mildew and fruit size. These parameters are therefore presented as average of cvs. LED lighting increased yield the first year (cycle 1) compared with control, with highest total yield under 

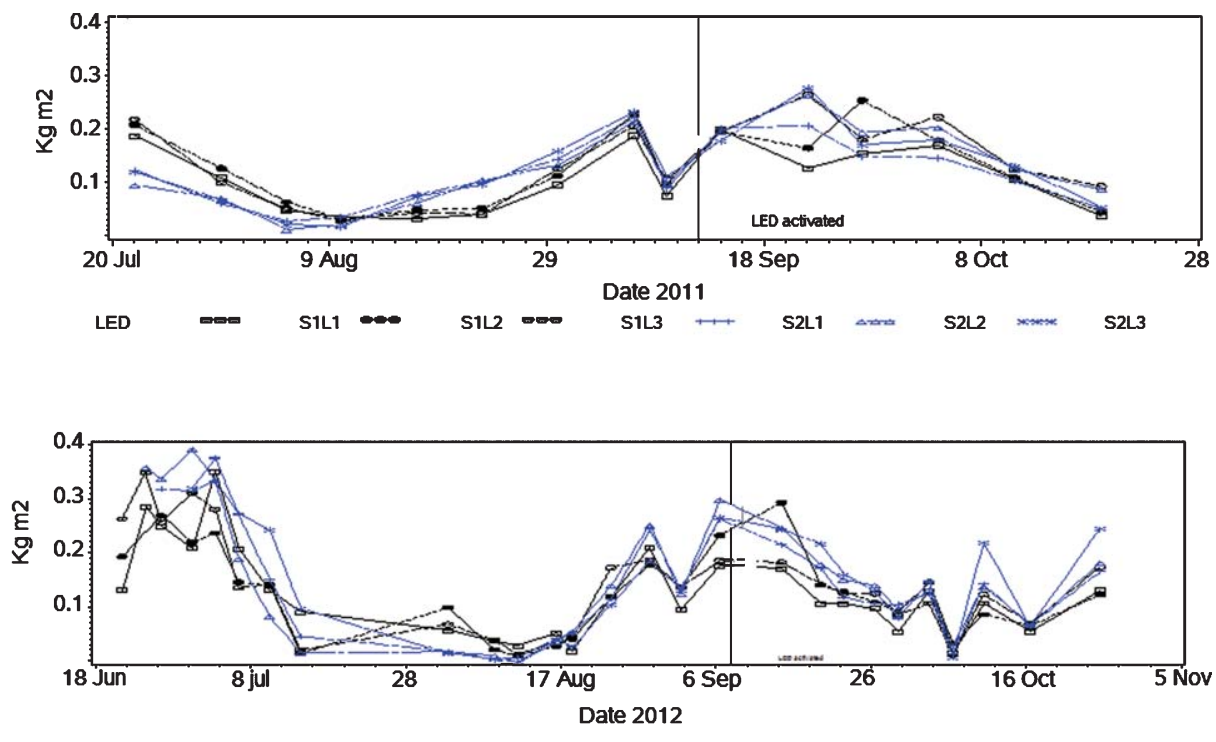

Fig. 1. Accumulated total fruit yield of two remontant strawberry cultivars (Fragaria x ananassa), Rondo (S1, black) and Everest (S2, blue), at three levels of light; L1 = control, L2 = LED 100W, L3 = LED 300W, grown in polytunnel in mid-Norway.
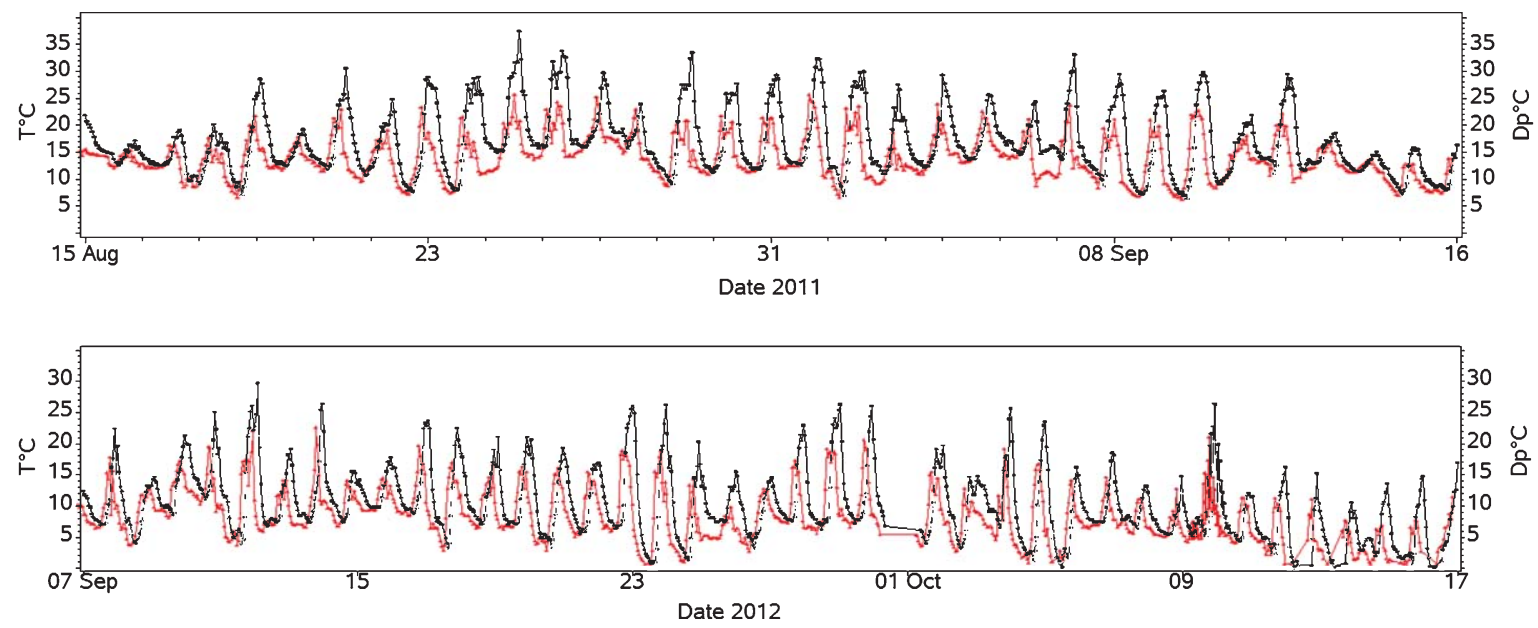

Fig. 2. Temperature and dew-point in autumn of two years.

LED 300W lamps (Table 1). There were no differences in percentage of salable fruits or percentage mildew among the three light levels.

In the second experimental year (2012) plants developed two full fruiting cycles. The first started one month earlier than the previous year, peaked 1 July and ended approximately 13 July. The second cycle started approximately 1 August, peaked 6 September, and harvest was stopped 24 October for similar reasons as previous year (Fig. 2). Average total yield tended to be higher under $300 \mathrm{~W}$ lamps in cycle- 2 than for control and $100 \mathrm{~W}$ lamps, and in cycle 3 both LEDs tended to give higher yield than control $(\% P=0.07-0.10$, respectively). Since no LED was activated in cycle-2 (early summer) the observed tendency of higher yield under LED300W compared with other treatments, 
Table 1

Effect of supplemental LED- lighting on total yield in $\mathrm{kg} \mathrm{m}^{2}, \%$ salable $(\% \mathrm{~S}), \%$ fruit with mildew (\% Md) and fruit size (Fs) in $\mathrm{g} / \mathrm{fruit}$ for crop cycles in 2011 and 2012, as average of two remontant strawberry cultivars grown in polytunnel in mid-Norway

\begin{tabular}{|c|c|c|c|c|c|}
\hline Cycle & LED & Yield & $\% \mathrm{~S}$ & $\% \mathrm{Md}$ & Fs \\
\hline \multirow[t]{5}{*}{$1(2011)$} & Control & 1.70 & 56.2 & 23.4 & 15.3 \\
\hline & 100W & 1.92 & 58.5 & 18.4 & 15.3 \\
\hline & $300 W$ & 1.97 & 54.0 & 28.9 & 16.5 \\
\hline & Mean & 1.86 & 56.2 & 23.6 & 15.7 \\
\hline & $\mathrm{Se}$ & $0.07^{* *}$ & $2.8^{\mathrm{ns}}$ & $3.8^{\mathrm{ns}}$ & $0.7^{\mathrm{ns}}$ \\
\hline \multirow[t]{5}{*}{$2(2012)$} & Control & 2.09 & 70.3 & 1.6 & 11.7 \\
\hline & $100 \mathrm{~W}$ & 2.01 & 72.4 & 0.2 & 11.3 \\
\hline & $300 \mathrm{~W}$ & 2.26 & 76.1 & 0.3 & 12.0 \\
\hline & Mean & 2.12 & 72.9 & 0.7 & 11.7 \\
\hline & $\mathrm{Se}$ & $0.08^{\mathrm{ns}}$ & $1.6^{*}$ & $0.7^{\mathrm{ns}}$ & $0.4^{\mathrm{ns}}$ \\
\hline \multirow[t]{5}{*}{3 (2012) } & Control & 1.90 & 67.9 & 10.7 & 12.8 \\
\hline & $100 \mathrm{~W}$ & 2.15 & 79.0 & 0.8 & 12.5 \\
\hline & $300 \mathrm{~W}$ & 2.10 & 73.7 & 4.6 & 13.3 \\
\hline & Mean & 2.05 & 73.5 & 5.4 & 12.9 \\
\hline & $\mathrm{Se}$ & $0.09^{\mathrm{ns}}$ & $5.7^{\mathrm{ns}}$ & $6.1^{\mathrm{ns}}$ & $0.4^{\mathrm{ns}}$ \\
\hline \multirow[t]{5}{*}{ Average } & Control & 1.90 & 64.8 & 11.9 & 13.3 \\
\hline & 100W & 2.03 & 70.0 & 6.5 & 13.0 \\
\hline & $300 \mathrm{~W}$ & 2.11 & 67.9 & 11.3 & 13.9 \\
\hline & Mean & 2.01 & 67.6 & 9.9 & 13.4 \\
\hline & $\mathrm{Se}$ & $0.07^{*}$ & $3.6^{\mathrm{ns}}$ & $4.1^{\mathrm{ns}}$ & $0.5^{\mathrm{ns}}$ \\
\hline
\end{tabular}

could be the result of improved flower -initiation and -development caused by supplemental light (12 September-18 October) of previous year (Fig. 1, Table 1).

\subsection{Effects of cultivar on fruit yield parameters}

Between cvs there were clear differences in total yield, \% salable and mildew infected fruit, but not in fruit size in average of the three cycles (Table 2). However, in cycle-1 there were no differences in yield and fruit size, but 'Everest' had more salable fruit and less mildew infected fruit than 'Rondo' which is very susceptible to mildew (Podosphaera aphanis). 'Everest' out-yielded 'Rondo' in cycle-2 and cycle-3, but fruit size was equal. The mildew infection was less problematic for 'Rondo' in these two cycles.

This show that LED lighting and cultivar had positive influence on fruit yield, and that cultivars reacted differently on mildew infection. However, day temperatures were often below $15^{\circ} \mathrm{C}$ in daytime beyond 15 September, in both years. Low temperatures reduce photosynthesis and the potential of supplemental light is much less utilized than at optimal temperatures of $22-25^{\circ} \mathrm{C}[7,15]$. The improved percentage of salable fruit using LED300W is in agreement with others $[4,11]$, and it could be that the higher blue to red ration in the LED100W compared with LED300W and control, was the reason of reduced injury by mildew in 'Rondo' giving a higher percentage salable fruit. In greenhouse rose production blue light $(420$ to $520 \mathrm{~nm})$ reduced injury by mildew (P. pannosa) by $16.5 \%$ compared with white light [19].

\subsection{Effect of LED on fruit tension}

In the periods using LED in 2011 and 2012 fruit firmness was much higher in 'Everest' than in 'Rondo' for all light treatments (Table 3). Supplemental light had no effect on fruit firmness of 'Rondo' either year. However, for 
Table 2

Effect of remontant strawberry cultivars grown in polytunnel on total yield in $\mathrm{kg} \mathrm{m}^{2}, \%$ salable $(\% \mathrm{~S}), \%$ fruit with mildew (\% Mp) and fruit size (Fs) in g/fruit for crop cycles in 2011 and 2012, in average of three levels of supplemental LED in mid-Norway

\begin{tabular}{|c|c|c|c|c|c|}
\hline Cycle & Cultivar & Yield & $\% \mathrm{~S}$ & $\% \mathrm{Mp}$ & Fs \\
\hline \multirow[t]{4}{*}{$1(2011)$} & Rondo & 1.87 & 33.5 & 46.2 & 16.0 \\
\hline & Everest & 1.86 & 79.0 & 0.9 & 15.5 \\
\hline & Mean & 1.87 & 56.3 & 23.6 & 15.8 \\
\hline & $\mathrm{Se}$ & $0.08^{\mathrm{ns}}$ & $3.4^{* * *}$ & $4,7^{* * *}$ & $0.9^{\mathrm{ns}}$ \\
\hline \multirow[t]{4}{*}{$2(2012)$} & Rondo & 1.83 & 71.3 & 1.1 & 12.3 \\
\hline & Everest & 2.42 & 74.5 & 0.2 & 11.0 \\
\hline & Mean & 2.13 & 72.9 & 0.7 & 11.7 \\
\hline & $\mathrm{Se}$ & $0.10^{* * *}$ & $2.0^{\mathrm{ns}}$ & $0.8^{\mathrm{ns}}$ & $0.5^{* *}$ \\
\hline \multirow[t]{4}{*}{3 (2012) } & Rondo & 1.86 & 66.0 & 10.4 & 13.1 \\
\hline & Everest & 2.24 & 81.2 & 0.3 & 12.6 \\
\hline & Mean & 2.05 & 73.6 & 5.6 & 12.9 \\
\hline & $\mathrm{Se}$ & $0.11^{* * *}$ & $6.9^{*}$ & $7.4^{\mathrm{ns}}$ & $0.5^{\mathrm{ns}}$ \\
\hline \multirow[t]{4}{*}{ Average } & Rondo & 1.85 & 56.9 & 19.3 & 13.8 \\
\hline & Everest & 2.17 & 78.2 & 0.5 & 13.0 \\
\hline & Mean & 2.01 & 67.6 & 9.9 & 13.4 \\
\hline & $\mathrm{Se}$ & $0.09^{* * *}$ & $4.5^{* * *}$ & $5.0^{* * *}$ & $0.6^{\mathrm{ns}}$ \\
\hline
\end{tabular}

Table 3

Effect on fruit tension at three light levels of two remonting strawberry cultivars, as average of two and four sampling dates in respectively 2011 and 2012 in mid-Norway

\begin{tabular}{|c|c|c|c|c|c|}
\hline \multirow[t]{2}{*}{ Cultivar } & \multicolumn{5}{|c|}{ Light 2011} \\
\hline & $\mathrm{C}$ & L1 & $\mathrm{L} 2$ & Mean & S. error \\
\hline Rondo & 157 & 153 & 160 & 157 & $8.7^{\mathrm{ns}}$ \\
\hline Everest & 254 & 260 & 286 & 267 & $10.3^{* *}$ \\
\hline Mean & 206 & 208 & 224 & 212 & $7.9^{*}$ \\
\hline$\underline{\text { S.error }}$ & $10.3^{*}$ & $9.2^{* * *}$ & $9.1^{* * *}$ & $9.7^{* * *}$ & \\
\hline \multirow[t]{2}{*}{ Cultivar } & \multicolumn{5}{|c|}{ Light 2012} \\
\hline & $\mathrm{C}$ & $\mathrm{L} 1$ & L2 & Mean & S.error \\
\hline Rondo & 184 & 168 & 158 & 170 & $8.4^{\mathrm{ns}}$ \\
\hline Everest & 342 & 362 & 375 & 360 & $11.7^{\mathrm{ns}}$ \\
\hline Mean & 263 & 265 & 267 & 265 & $13.9^{* * *}$ \\
\hline S.error & $13.0^{* * *}$ & $14.7^{* * *}$ & $16.1^{* * *}$ & $14.0^{* * *}$ & $13.9^{\mathrm{ns}}$ \\
\hline
\end{tabular}

'Everest' LED 300W lighting increased fruit tension in 2011 compared with other treatments, and in 2012 both LED lighting levels tended to improve fruit firmness, compared with control.

\subsection{Effect of LEDs on Brix ${ }^{\circ}$}

In periods using LED lighting in 2011 and 2012 the effects on Brix ${ }^{\circ}$ were clear (Fig. 3). The highest Brix ${ }^{\circ}$ value first year was for fruit harvested under LED300W lamps at both sampling dates, but also LED100W lamps improved Brix $^{\circ}$ level compared with control. 

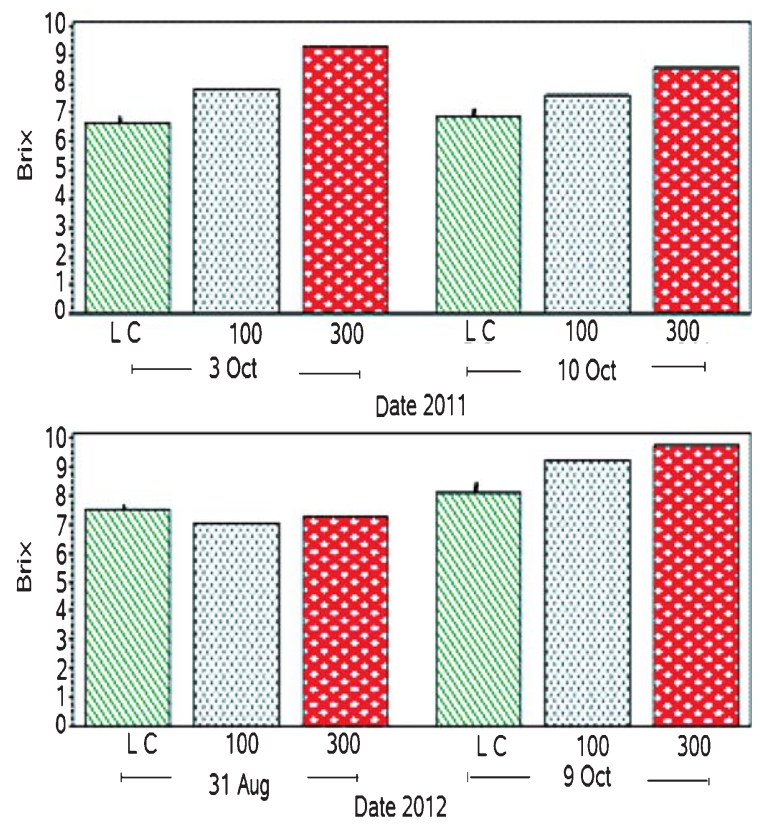

Fig. 3. Effects of LEDs on Brix level at two dates in Mid-Norway for two years, in average of two cultivars. The bars are standard errors at actual dates.

In 2012 first sampling date was 31 August, before light activation, while second sampling was undertaken one day earlier than previous year. The pattern of Brix ${ }^{\circ}$ between treatments was similar to previous year, but the levels were generally higher, probably due to higher temperatures in late autumn of 2012 than in 2011. This is in agreement with other reports showing that below optimum levels of temperature, light and $\mathrm{CO} 2$ reduce photosynthesis and thus production of sugar and other photosynthetic molecules [7, 15].

Average light intensities on cloudy days at top of canopy, between hours 14:00 and 15:00, under LED100W were in the periods: 1)17 Sep to 9 Oct and 2) after 9 Oct, respectively 481 and $258 \mu \mathrm{mol} \mathrm{m}^{-2} \mathrm{~s}^{-1}$. Average light level of LED300W lamps was near $900 \mu \mathrm{mol} \mathrm{m}^{-2} \mathrm{~s}^{-1}$ in both periods. Ambient light at the same periods and hours, when LED lamps were not active, was 432 and $291 \mu \mathrm{mol} \mathrm{m}^{-2} \mathrm{~s}^{-1}$, respectively. However, ambient light levels were lower in early morning and late evening than at daytime, and in addition LED lighting is near double as effective as high-intensity- discharge (HDI) lamps in the PAR-window (400 to $700 \mathrm{~nm}$ ), since PAR of ambient light and HDI lamps include wavelengths that are not effective in photosynthesis $[1,23]$. Considering existing knowledge of light effect of greenhouse lamps, other than LED, at optimal temperatures for strawberry $\left(22-25^{\circ} \mathrm{C}\right)$, it is suggested that $110 \mu \mathrm{mol} \mathrm{m} \mathrm{m}^{-2} \mathrm{~s}^{-1}$ give satisfactory fruit quality of 'Korona' and 'Elsanta', that $375.5 \mu \mathrm{mol} \mathrm{m}^{-2} \mathrm{~s}^{-1}$ give optimal growth for everbearing strawberry, and that the light saturation point for photosynthetic activity in strawberry is between 800-1000 $\mu \mathrm{mol} \mathrm{m}^{-2} \mathrm{~s}^{-1}$ at optimal temperature and ambient $\mathrm{CO}_{2}$ level $[2,3,5,7,12]$. Since LED lighting is more effective this indicate that levels of light given in our experiment have been high enough to improve fruit quality and growth and above the saturation point for photosynthesis for the LED300W lamps, especially late in the season when temperature was low. However, the experiments showed that Brix ${ }^{\circ}$ level was improved by LED100W lighting compared to ambient light, but even more by LED300W lighting. This suggest that LED lighting of more than $258 \mu \mathrm{mol} \mathrm{m}^{-2} \mathrm{~s}^{-1}$ improve fruit -yield and especially fruit-quality in periods with low ambient light, and that fruit quality and yield increased even more at LED lighting of $900 \mu \mathrm{mol} \mathrm{m}{ }^{-2} \mathrm{~s}^{-1}$. However the strongest light is probably much above the light saturation point for photosynthesis, especially late in October when temperatures were below optimum. To make it possible to improve harvest in October a tighter tunnel and supplemental heating is necessary. That will increase light efficiency and secure a high quality crop. It is also important to notice that the radiation given under the active lamps is a sum of LED and ambient radiation. 
Common arthropods on 'Rondo' leaves

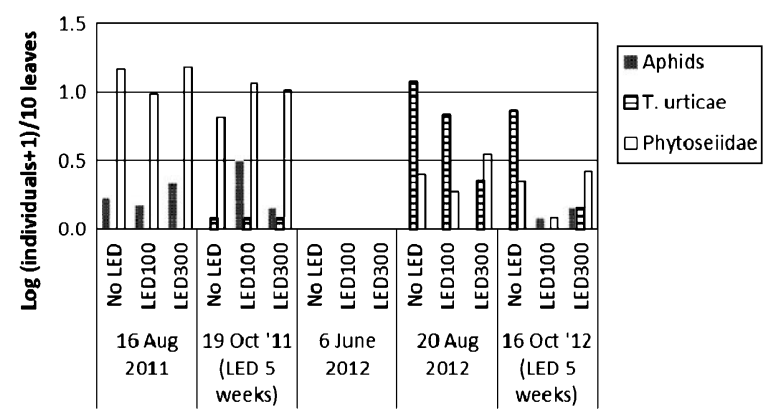

Fig. 4. Average numbers of arthropod specimens $\{\log (x+1)$ transformed $\}$ found per sample of 10 'Rondo' trifoliate leaves taken at five different times during the experiment. Only the three most common groups are shown; aphids = unidentified species, T. urticae = two-spotted spider mite, Phytoseiidae $=$ Neoseiulus cucumeris (introduced).

Table 4

light levels in $\mu \mathrm{mol} \mathrm{m}{ }^{-2} \mathrm{~s}^{-1}$ at top of canopy under LED lamps and in ambient light in periods when ambient light level was below $400 \mu \mathrm{mol} \mathrm{m}^{-2} \mathrm{~s}^{-1}$

\begin{tabular}{lccc}
\hline Light source & LED 100W & LED 300W & Ambient \\
\hline Light level & 258 & 900 & $100-400$ \\
\hline
\end{tabular}

\subsection{Effects on arthropod fauna}

Few arthropod groups were common on the 'Rondo' leaves: aphids (wingless females and nymphs, unidentified species) and predatory mites (Neoseiulus cucumeris) in 2011, and spider mites (Tetranychus urticae) and predatory mites in 2011 (Fig. 4). Thrips and gall midge larvae also occurred, but in too low numbers to be valuable for further analysis. Early in the second year (6 Jun 2012) very few arthropods were found.

The number of spider mites (motile stages) increased sharply from year one ( $N=3$ specimens found in total) to year two $(N=278)$, but in October of year two the plots receiving supplemental light had significantly less spider mites than control plots $\left(p=0.032, F_{2,9}=5.16\right)$. The reduced $T$. urticae abundance in LED plots could be due to direct effects \{e.g., blue light inducing diapause [20], or indirect effects mediated by the plant (e.g., higher light intensity improving plant defence [16]) or both\}. None of these mechanisms was studied in the experiments, but the results on berry quality clearly demonstrate that LED treatments influenced plant physiology. Indirect effects through the predator N. cucumeris were not evident (see below).

The numbers of aphids and predatory mites did not differ significantly among light treatments. Phytoseiids were more numerous in the autumn of year one than in year two, which could reflect the different types and release times of $N$. cucumeris sachets used, or the predatory mites profiting on honeydew (aphids being more abundant in year 1) or another non-T. urticae food source in year one. There was no correlation between numbers of spider mites and predatory mites per plot on any of the sampling occasions, confirming that $N$. cucumeris is not an optimal biocontrol agent for T. urticae [18].

\section{Conclusions}

LED lighting above $250 \mu \mathrm{mol} \mathrm{m} \mathrm{m}^{-2} \mathrm{~s}^{-1}$ can facilitate harvest of a high quality second crop of remontant strawberry growing in standard high polytunnels. Higher light intensity would increase yield and fruit quality even more. The regime of LED supplemental light used in this experiment did not lead to higher pest populations; on the contrary, 
spider mite numbers in the autumn decreased. To achieve the full benefit of supplemental light, reduce fruit rot and secure a full crop in late autumn, a winter polytunnel with supplemental heat would be necessary.

\section{Acknowledgments}

These experiments are a part of the EUBerry project funded by the "Seventh Framework programme" of EU, under call FP7-KBBE-2010-4, grant agreement no: 265942. We thank Sigrid Alstad for help with technical field support and securing of field data, and Karin Westrum and Toril S Eklo for sorting and counting arthropod.

\section{References}

[1] Campbell NA, Reece JB, Urry LA, Cain ML, Wasserman SA, Minorsky PV, Jackson RB. Biology. Chapter 10 Photosynthesis. Editor B. Commings, Pearson Education eight edition 2013. pp. 185-205.

[2] CheonSoon J, YongRog Y, IlSeop K, SangSoo K, DongHa C. Effects of CO2 enrichment on the net photosynthesis, yield, content of sugar and organic acid in strawberry fruits. Journal of the Korean Society for Horticultural Science. 1996;37:736-40 (English abstract).

[3] Elsacker P, Impens I, Liesse H. Photosynthesis-response surface of strawberry in relation to light, CO2 and temperature. Revue de l'Agriculture. 1989;42:649-62 (English abstract).

[4] Fletcher JM, Sutherland ML, Ames JM, Battey NH. The effect of light integral on vegetative growth and fruiut yield of 'Elsanta' strawberry. Strawberry research to 2001: Proceedings of the 5th North American Strawberry Conference 2002. 2002; pp. 157-60.

[5] Haffner K, Vesterheim S, Fjelltun M. Quality criteria of greenhouse or field grown strawberry cv, 'Korona' and 'Elsanta'. Erwerbsobstbau. 1997;39:65-71 (In German).

[6] Johansen NS, Vänninen I Pinto DM, Nissinen AI and Shipp L. In the light of new greenhouse technologies: 2. Direct effects of artificial lighting on arthropods and integrated pest management in greenhouse crops. Annals of Applied Biology. 2011;159:1-27.

[7] Larcher W. Physiological plant ecology. Echophysiology and stress physiology of functional groups Chapter 2.2.5.2. Responses of respiration and photosynthesis to temperature. ISBN 3-540-43516 Springer-Verlag Berlin Heidelberg New York. 2003; pp. 120-6.

[8] Luczynski A, Isman MB, Raworth DA. Strawberry foliar phenolics and their relationship to development of the two-spotted spider mite. J Econ Entomol. 1990;83:557-63.

[9] McKeown A, Gardner G. Climate change reference guide. The World Watch Institute, ISBN78-1-878071-88-0 (13) 2009. 30pp.

[10] Minitab 16.1.0, Minitab Inc (2010).

[11] Miura H, Yoshida M, Yamasaki A. Effect of light intensity on growth and ripening of strawberry fruit. Acta Horticulturae. 1993;348:78 (English abstract).

[12] Miyazawa Y, Hikosaka S, Goto E, Aoki T, Effects of light conditions and air temperature on the growth of everbearing strawberry during the vegetative stage. Acta Horticulturae. 2009;842:817-20.

[13] Noga GJ. From vision to reality: Horticulture at the forefront of innovation. Chronica Horticulturae. 2012;52(4):3-4.

[14] Nordengen I, Klingen I. Comparison of methods for estimating the prevalence of Neozygites floridana in Tetranychus urticae populations infesting strawberries. Journal of Invertebrate Pathology. 2006;92:1-6.

[15] Oda Y. Effects of light intensity, $\mathrm{CO} 2$ concentration and leaf temperature on gas exchange of strawberry plants -feasibility studies on CO2 enrichment in Japanese conditions. Acta Horticulturae. 1997;439:563-573.

[16] Patterson CG, Archbold DD, Rodriguez JG, Hamilton-Kemp TR. Daylength and resistance of strawberry foliage to the twospotted spider mite. Hortscience. 1994;29:1329-31.

[17] SAS, Proc -GLM, -Tabulate, -Graph and -Gereplay. Version SAS 9.2. SAS Institute Inc., Cary, NC, USA, 2009.

[18] Shimoda T, Kishimoto H, Takabayashi J, Amano H, Dicke M. Relationships between the ability to penetrate complex webs of Tetranychus spider mites and the ability of thread-cutting behavior in phytoseiid predatory mites. Biological Control. 2010;53:273279.

[19] Suthaparan A, Torre S, Stensvand A, Herrero LM, Pettersen RI, Gadoury DM, Gislerød HR. Specific light-emitting-diodes can suppress sporulation of Podospaera pannosa on greenhouse roses. Plant disease. 2010;94:1105-10.

[20] Suzuki T, Fukunaga Y, Amano H, Takeda M, Goto E. Effects of light quality and intensity on diapause induction in the two-spotted spider mite, Tetranychus urticae. Appl Entomol Zool. 2008;43:213-18.

[21] Vänninen I, Pinto DM, Nissinen AI, Johansen NS, Shipp L. In the light of new greenhouse technologies: 2. Direct effects of artificial lighting on arthropods and integrated pest management in greenhouse crops. Annals of Applied Biology. 2011;159:1-27.

[22] Wada Y, Soeno T, Inaba Y. Effects of light and temperature on photosynthetic enhancement by high CO2 concentration of strawberry cultivar Tochiotome leaves under forcing or half-forcing culture. Japanese Journal of Crop Science. 2010;79:192-7 (English abstract).

[23] Wells K. How to specify LED lighting. Greenhouse Product News, Available online: www.gpnmag.com, January 2013, pp. 28-30. 
[24] Yangi T, Okamota K and Takita S. Effect of blue and red light intensity on photosynthetic rate of strawberry leaves. Acta Horticulturae. 1996;440:371-6.

[25] YanPing L, HongMei M, JingJing W, Guojie L, Yusufu S. Effects of DA-6 on leaf photosynthesis and antioxidant enzyme activities of strawberry under different light intensiries. Journal of China Agricultural University. 2011;16:71-6 (English abstract).

[26] Zilahi-Balogh GMG, Shipp JL, Cloutier C, Brodeur J. Predation by Neoseiulus cucumeris on western flower thrips, and its oviposition on greenhouse cucumber under winter vs. summer conditions in a temperate climate. Biological Control. 2007;40:160-7. 